\title{
PENGARUH MODEL PROBLEM BASED LEARNING TERHADAP KETUNTASAN HASIL BELAJAR PESERTA DIDIK KELAS VII SMP
}

\author{
Fitriana Nur Suhailah \\ Universitas Hasyim Asy’ari Tebuireng Jombang \\ Nur Kuswanti \\ Universitas Negeri Surabaya \\ Universitas Hasyim Asy’ari Tebuireng Jombang \\ Nur Hayati \\ Universitas Hasyim Asy’ari Tebuireng Jombang
}

\begin{abstract}
Abstrak
Penelitian ini bertujuan untuk (1) mendeskripsikan ketuntasan belajar peserta didik setelah pembelajaran dengan menggunakan model pembelajaran Problem Based Learning (PBL); (2) mendeskripsikan pengaruh model pembelajaran Problem Based Lerning (PBL) terhadap hasil belajar peserta didik. Populasi penelitian ini adalah seluruh peserta didik kelas VII SMP. Sampel diambil dengan teknik purposive sampling sebanyak 2 kelas dari 10 kelas. Pengambilan data dilakukan di semester 2 di kelas VII tahun ajaran 2018/2019. Penelitian ini menggunakan jenis penelitian quasy experimental design. Desain penelitian adalah posttest-only control design. Instrumen penelitian yaitu instrumen kuantitatif, berupa lembar soal posttest. Teknik pengumpulan data menggunakan metode tes berupa posttest. Hasil penelitian yang diperoleh menunjukkan bahwa rata-rata ketuntasan indikator pembelajaran pada kelas kontrol sebesar 76 . Sedangkan pada kelas eksperimen sebesar 89,3. Hasil belajar peserta didik dengan model pembelajaran PBL lebih tinggi dari hasil belajar peserta didik dengan metode ceramah yang

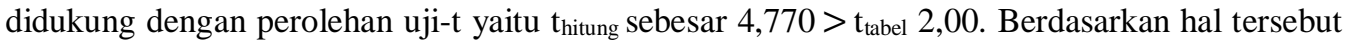
dapat disimpulkan bahwa model pembelajaran Problem Based Learning mempengaruhi hasil belajar peserta didik Kelas VII SMP.
\end{abstract}

Kata Kunci: Problem Based Learning, Ketuntasan Indikator Pembelajaran, Hasil Belajar.

\begin{abstract}
This study aimed to: (1) describe the mastery of student learning outcome after learning using the Problem Based Learning (PBL) Model; (2) describe the influence of the Problem Based Lerning (PBL) Model to student learning outcome. The population of this research was all students of class VII of Junior High School. This study used purposive sampling techniques, with 2 classes. Collecting data was conducted in semester 2 of the 2018/2019 academic year. This research used quasy experimental design. The form of research was posttest-only control design. It's instruments was a quantitative instrument, in the form of a posttest question sheet. Data collection techniques was a test method in the form of posttest. The results of the study showed that the mastery of the learning indicators in the control class was 76. While in the experimental class the mastery of learning indicators was 89.3. The result of independent samples test (t-test) that showed probability of $4.770>2.00$. Based these data, it can be concluded that, the Problem Based Learning model influenced the learning outcomes of students of State Junior High School. Keywords: Problem Based Learning, Completeness of Learning Indicators, Learning Outcomes.
\end{abstract}

\section{PENDAHULUAN}

Ilmu Pengetahuan Alam (IPA) diartikan sebagai suatu pengetahuan yang sistematis, serta dihubungkan dengan lingkungan alam yang diperoleh dengan hasil observasi dan pengamatan. Pendidikan IPA menitikberatkan pada pemberian pengalaman langsung kepada peserta didik untuk memperoleh pengetahuan dalam mengembangkan kompetensi dengan cara memahami dan menjelajahi lingkungan yang ada di sekitar (Kemendikbud, 2014b). Oleh karena itu, dalam proses pembelajaran IPA, pendidik lebih mengedepankan pada 
pengalaman personal menggunakan pendekatan saintifik melalui proses mengamati, menanya, menalar, mencoba, menciptakan dan mengkomunikasikan untuk meningkatkan kreativitas peserta didik (Kemdikbud, 2014a).

Permendikbud tahun 2016 nomor 21 tentang Standar Isi Pendidikan, menjelaskan bahwa kompetensi pada Mata Pelajaran Ilmu Pengetahuan Alam (IPA) meliputi: (1) memiliki sifat ilmiah: memiliki rasa ingin tahu yang tinggi, berpikir logis, berpikir kritis, jujur, analitis dan bertanggung jawab melalui IPA; (2) dapat mengajukan sebuah pertanyaan tentang fenomena IPA, melakukan percobaan, mengumpulkan dan menyajikan hasil penyelidikan, menyimpulkan serta membuat laporan hasil penyelidikan; dan (3) mampu memahami prinsip dan konsep IPA serta saling keterkaitannya dan mampu menerapkannya dalam mengatasi masalah kehidupan. Pada saat ini sistem pendidikan di Indonesia menggunakan acuan Kurikulum 2013. Permendikbud No. 22 Tahun 2016, kurikulum 2013 menghendaki perubahan tentang prinsip pembelajaran yaitu dari peserta didik diberi tahu menjadi peserta didik mencari tahu, dari pendekatan tekstual menuju penggunaan pendekatan ilmiah. Untuk memperkuat pendekatan ilmiah (scientific) dalam suatu pembelajaran perlu diterapkan pembelajaran berbasis masalah (problem based learning) agar dapat mendorong peserta didik bisa menyelesaikan permasalahan secara nyata. Dalam hal ini, pengetahuan peserta didik diperoleh melalui proses pemecahan masalah, sehingga peserta didik dapat menemukan sendiri pengetahuannya.

Berdasarkan hasil observasi dan wawancara dengan salah satu guru mata pelajaran IPA kelas VII, beberapa masalah yang ditemukan diantaranya, (1) hasil belajar peserta didik masih tergolong rendah dengan rata-rata kelas sebesar 68,03; (2) kurangnya kemampuan peserta didik dalam mengajukan pertanyaan serta mengemukakan pendapat; (3) pada materi pencemaran lingkungan, belum melibatkan permasalahan autentik yang ada di kehidupan nyata dan belum melibatkan penggunaan pemecahkan masalah terhadap lingkungan secara langsung. Permasalahan tersebut diperkuat dengan data hasil rekapitulasi penyebaran angket yang diberikan kepada peserta didik yang menunjukkan bahwa hanya $36,66 \%$ peserta didik atau sekitar 11 peserta didik dari 31 yang menyukai pelajaran IPA, persentase tersebut sangat rendah. Sebanyak 63,33\% peserta didik menganggap bahwa proses pembelajaran IPA membosankan dan kurang bervariasi. Pelaksanaan pembelajaran IPA di kelas kurang dikemas secara menarik sehingga cenderung membosankan. Peserta didik kurang terlibat dalam proses pembelajaran. Akibatnya jika diberi masalah yang ada di lingkungan sekitar, peserta didik kurang termotivasi untuk memecahkannya dan secara tidak langsung pembelajaran IPA menjadi kurang bermakna.

Pada mata pelajaran IPA khususnya Biologi materi pencemaran lingkungan, peserta didik dituntut untuk menyelesaikan masalah, mendeskripsikan dan menyajikan hasil observasi tentang pencemaran lingkungan. Materi pencemaran lingkungan membutuhkan objek nyata dari lingkungan sekitar sebagai sumber belajar. Diperlukan kegiatan yang mengarahkan peserta didik untuk terlibat aktif memanfaatkan lingkungan sebagai sumber belajar dalam memahami konsep.

Upaya untuk mengatasi permasalahan yang dihadapi pendidik maupun peserta didik tersebut, salah satunya adalah dengan menerapkan model pembelajaran yang berbasis penelitian atau penyingkapan suatu permasalahan yakni model pembelajaran problem based learning (PBL). Menurut 
Arends (2008), PBL merupakan pembelajaran yang diorganisasikan melalui pertanyaan dan masalah yang penting secara sosial dan bermakna secara personal bagi peserta didik. PBL merupakan sebuah model pembelajaran yang menggunakan masalah dalam kehidupan sehari-hari sebagai pembelajaran bagi peserta didik untuk mengasah kemampuan memecahkan masalah dan memperoleh konsep IPA yang esensial dari materi pelajaran.

Sintaks pelaksanaan PBL terdiri atas 5 fase pembelajaran sebagai berikut: (1) memberikan orientasi permasalahan kepada peserta didik; (2) mengorganisasikan peserta didik untuk meneliti; (3) membantu investigasi mandiri dan kelompok; (4) mengembangkan dan mempresentasikan hasil karya (exhibit); serta (5) menganalisis dan mengevaluasi proses mengatasi masalah (Arends, 2008),. Sesuai dengan proses pembelajaran PBL, peserta didik diharap mampu berpikir kritis dalam mengenal dan memecahkan masalah, membuat hipotesis, membuat kesimpulan dan mengembangkan pendapatnya di depan kelas sehingga dapat meningkatkan hasil belajar yang didapat oleh peserta didik. Oleh karena itu, dapat disimpulkan bahwa PBL merupakan pembelajaran inovatif dengan memberikan kondisi aktif dalam pembelajaran yang mendukung peserta didik berpikir kritis dan mempunyai keterampilan dalam memecahkan suatu permasalahan dengan menggunakan masalah dunia nyata.

Hal ini sejalan dengan hasil penelitian Yulianingtias dkk, (2016) menunjukkan bahwa model pembelajaran Problem Based Learning (PBL) memiliki pengaruh terhadap hasil belajar peserta didik. Hasil uji-t menunjukkan bahwa hasil belajar IPA kelas eksperimen yang dibelajarkan dengan model PBL meningkat lebih signifikan dibandingkan dengan kelas kontrol. Ratarata hasil nilai posttest peserta didik sesudah perlakuan pada kelas eksperimen yaitu 78,7, lebih tinggi dibandingkan dengan rata-rata nilai posttest peserta didik kelas kontrol yaitu 66,7 .

Berdasarkan uraian tersebut maka dilaksanakan penelitian untuk mengetahui pengaruh model Problem Based Learning (PBL) terhadap hasil belajar peserta didik kelas VII SMP.

\section{METODE}

Penelitian dilaksanakan pada salah satu SMP Negeri Jombang Tahun Ajaran 2018/2019. Sampel adalah 2 kelas yang diambil dari 10 kelas secara purposive sampling. Data diambil dengan menggunakan metode quasy experimental design. Penelitian ini menggunakan posttestonly control design dengan rancangan penelitian sebagai berikut :

Tabel 1. Rancangan Penelitian

\begin{tabular}{|l|c|c|}
\hline \multicolumn{1}{|c|}{ Subjek } & $\begin{array}{c}\text { Variabel } \\
\text { Bebas }\end{array}$ & $\begin{array}{c}\text { Variabel } \\
\text { Terikat }\end{array}$ \\
\hline Eksperimen & $\mathrm{X}_{1}$ & $\mathrm{O}_{1}$ \\
\hline Kontrol & $\mathrm{X}_{2}$ & $\mathrm{O}_{2}$ \\
\hline Keterangan: \\
$\mathrm{X}_{1}=\begin{array}{l}\text { perlakuan dengan menggunakan } \\
\text { model PBL }\end{array}$ \\
$\mathrm{X}_{2}=\begin{array}{l}\text { perlakuan dengan menggunakan } \\
\text { metode ceramah }\end{array}$ \\
$\mathrm{O}_{1}=\begin{array}{l}\text { hasil posttest (setelah diberi perlakuan } \\
\text { dengan menggunakan model PBL) }\end{array}$ \\
$\mathrm{O}_{2}=\begin{array}{l}\text { hasil posttest (setelah diberi perlakuan } \\
\text { dengan menggunakan metode } \\
\text { ceramah) }\end{array}$
\end{tabular}

Instrumen penelitian ini berupa lembar soal posttest yang terdiri 10 soal pilihan ganda. Teknik pengumpulan data yang digunakan dalam penelitian ini berupa soal tes kognitif. Uji statistik dilakukan pada taraf signifikan 5\% $(0,05)$, dalam penelitian ini persyaratan yang harus dipenuhi terlebih dahulu yaitu uji prasyarat analisis yang meliputi uji normalitas dan uji homogenitas varians. Uji hipotesis pada penelitian ini digunakan untuk mengetahui pengaruh hasil belajar peserta didik antara kelas eksperimen dan kelas kontrol dengan menggunakan statistika Uji Independent Samples Test (ujit). Uji-t digunakan untuk membuktikan hipotesis pada taraf signifikasi 5\% $(0,05)$. 
HASIL DAN PEMBAHASAN

Berdasarkan hasil analisis dat yang telah dilakukan, Data hasil belajar pada kelas kontrol dan kelas eksperimen dapat dilihat pada Tabel 2.

Tabel 2. Hasil Posttest Kelas Kontrol dan Eksperimen

\begin{tabular}{|c|c|c|c|c|c|}
\hline \multirow{2}{*}{ PD ke- } & \multicolumn{2}{|c|}{ Posttest Kelas Kontrol } & \multirow{2}{*}{ PD ke- } & \multicolumn{2}{|c|}{ Posttest Kelas Eksperimen } \\
\cline { 5 - 6 } & $\mathbf{N}$ & $\mathbf{K}$ & $\mathbf{N}$ & $\mathbf{K}$ \\
\hline 1. & 70 & Tidak Tuntas & 1. & 80 & Tuntas \\
\hline 2. & 90 & Tuntas & 2. & 90 & Tuntas \\
\hline 3. & 70 & Tidak Tuntas & 3. & 80 & Tuntas \\
\hline 4. & 80 & Tuntas & 4. & 100 & Tuntas \\
\hline 5. & 80 & Tuntas & 5. & 100 & Tuntas \\
\hline 6. & 90 & Tuntas & 6. & 90 & Tuntas \\
\hline 7. & 80 & Tuntas & 7. & 100 & Tuntas \\
\hline 8. & 70 & Tidak Tuntas & 8. & 90 & Tuntas \\
\hline 9. & 80 & Tuntas & 9. & 80 & Tuntas \\
\hline 10. & 70 & Tidak Tuntas & 10. & 90 & Tuntas \\
\hline 11. & 80 & Tuntas & 11. & 100 & Tuntas \\
\hline 12. & 70 & Tidak Tuntas & 12. & 80 & Tuntas \\
\hline 13. & 70 & Tidak Tuntas & 13. & 100 & Tuntas \\
\hline 14. & 80 & Tuntas & 14. & 100 & Tuntas \\
\hline 15. & 80 & Tuntas & 15. & 100 & Tuntas \\
\hline 16. & 70 & Tidak Tuntas & 16. & 100 & Tuntas \\
\hline 17. & 100 & Tuntas & 17. & 100 & Tuntas \\
\hline 18. & 100 & Tuntas & 18. & 70 & Tidak Tuntas \\
\hline 19. & 90 & Tuntas & 19. & 100 & Tuntas \\
\hline 20. & 80 & Tuntas & 20. & 80 & Tuntas \\
\hline 21. & 70 & Tidak Tuntas & 21. & 90 & Tuntas \\
\hline 22. & 80 & Tuntas & 22. & 90 & Tuntas \\
\hline 23. & 70 & Tidak Tuntas & 23. & 70 & Tidak Tuntas \\
\hline 24. & 80 & Tuntas & 24. & 80 & Tuntas \\
\hline 25. & 80 & Tuntas & 25. & 100 & Tuntas \\
\hline 26. & 80 & Tuntas & 26. & 100 & Tuntas \\
\hline 27. & 70 & Tidak Tuntas & 27. & 90 & Tuntas \\
\hline 28. & 80 & Tuntas & 28. & 100 & Tuntas \\
\hline 29. & 70 & Tidak Tuntas & 29. & 90 & Tuntas \\
\hline 30. & 70 & Tidak Tuntas & 30. & 90 & Tuntas \\
\hline 31. & 60 & Tidak Tuntas & 31. & 60 & Tidak Tuntas \\
\hline RRK & 77 & TT & RRK & 90 & T \\
\hline
\end{tabular}

Keterangan:

Tidak Tuntas

Tuntas

$=\mathrm{N}<78)$

PD Ke-

$=\mathrm{N} \geq 78)$

$\mathrm{N}$

$=$ Peserta Didik Ke-

$\mathrm{K}$

$=$ Nilai

$=$ Keterangan

Berdasarkan Tabel 2. diperoleh data sebanyak 31 peserta didik kelas kontrol memperoleh nilai posttest terendah sebesar 60 dan nilai tertingginya adalah 100 . Sebanyak 13 peserta didik memperoleh predikat belum tuntas karena nilai yang telah diperoleh kurang dari 78 dan sebanyak 18 peserta didik memperoleh predikat tuntas karena nilai yang telah diperoleh lebih dari 78. Pada kelas eksperimen sebanyak 32 peserta didik memperoleh nilai posttest terendah yaitu 60 dan nilai tertinggi yaitu 100, sama dengan nilai terendah dan tertinggi pada kelas kontrol. Sebanyak 3 peserta didik memperoleh predikat belum tuntas karena nilai yang telah diproleh 
kurang dari 78 dan 28 peserta didik lainnya memperoleh predikat tuntas karena nilai yang telah diperoleh lebih dari 78. Kriteria ketuntasan tersebut mengacu pada Kriteria Ketuntasan Minumum (KKM) yang telah di tetapkan yaitu sebesar $\geq 78$. Berikut perbandingan ketuntasan belajar antara kelas kontrol dan kelas eksperimen.

Tabel 3. Perbandingan Ketuntasan Belajar Kelas Kontrol dan Kelas Eksperimen

\begin{tabular}{|c|c|c|}
\hline & $\begin{array}{c}\text { Kelas } \\
\text { Kontrol }\end{array}$ & $\begin{array}{c}\text { Kelas } \\
\text { Eksperimen }\end{array}$ \\
\hline Ketuntasan & $58,06 \%$ & $90,32 \%$ \\
\hline
\end{tabular}

Perbandingan ketuntasan indikator pembelajaran antara kelas kontrol dan kelas eksperimen disajjikan dalam diagram batang pada Gambar 1 berikut.

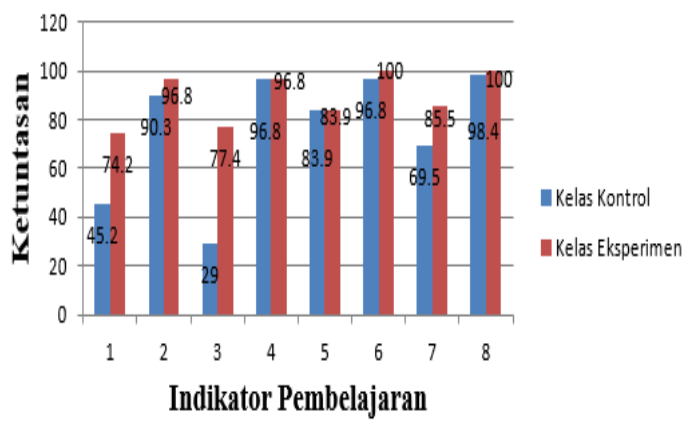

Gambar 1. Perbandingan Ketuntasan Indikator Pembelajaran antara Kelas

Keterangan:

Indikator Pembelajaran ke-

1. Menjelaskan pengertian pencemaran lingkungan

2. Menjelaskan jenis-jenis pencemaran

3. Menjelaskan pengertian pencemaran air

4. Mengidentifikasi contoh pencemaran air yang ada di lingkungan sekitar

5. Mengidentifikasi faktor penyebab adanya pencemaran air

6. Mengidentifikasi ciri-ciri air bersih dan tercemar

7. Memprediksi dampak negatif dari pencemaran air

8. Menentukan upaya untuk menanggulangi adanya pencemaran air

Pada kelas kontrol dibelajarkan dengan menggunakan metode ceramah sedangkan pada kelas eksperimen menggunakan model Problem Based Learning (PBL). Hal tersebut mempengaruhi hasil belajar yang diperoleh peserta didik antara kelas kontrol dan kelas eksperimen. Pengaruh model pembelajaran Problem Based Learning (PBL) terhadap hasil belajar peserta didik dapat dilihat dari hasil analisis statistik yang telah dilakukan sebagai berikut.

\section{Uji Prasyarat Analisis Uji Normalitas Data}

Hasil uji normalitas data yang berupa posttest pada kelas kontrol dan kelas eksperimen disajikan pada Tabel 4 berikut.

Tabel 4. Hasil Uji Normalitas Posttest pada Kelas Kontrol dan Kelas Ekspeerimen

\begin{tabular}{|l|l|l|}
\hline Kelas & $\begin{array}{l}\text { Nilai } \\
\text { Sig }\end{array}$ & Kesimpulan \\
\hline Posttest Kontrol & 0,053 & Normal \\
\hline $\begin{array}{l}\text { Posttest } \\
\text { Eksperimen }\end{array}$ & 0,058 & Normal \\
\hline
\end{tabular}

Tabel 4 menunjukkan bahwa hasil uji normalitas posttest pada kelas kontrol mendapatkan nilai signifikasi sebesar 0,053. Sedangkan hasil uji normalitas posttest pada kelas eksperimen mendapatkan nilai signifikasi sebesar 0,058. Sebuah data dapat dikatakan berdistribusi normal apabila nilai signifikasi > 0,05. Hasil uji normalitas posttest baik kelas kontrol maupun kelas eksperimen memiliki nilai signifikasi $>0,05$, maka dapat disimpulkan bahwa kelompok data tersebut berdistribusi normal.

\section{Uji Homogenitas Varians Data}

Hasil uji homogenitas data pada kelas kontrol dan kelas eksperimen dapat dilihat pada Tabel 5 berikut.

Tabel 5. Hasil Uji Homogenitas Posttest pada Kelas Kontrol dan Kelas Eksperimen

\begin{tabular}{|l|l|l|l|}
\hline Kelas & F $_{\text {hitung }}$ & Sig & Kesimpulan \\
\hline $\begin{array}{l}\text { Posttest Kelas } \\
\text { Kontrol dan } \\
\text { Eksperimen }\end{array}$ & 0,609 & 0.438 & Homogen \\
\hline
\end{tabular}

Hasil uji homogenitas variabel penelitian diketahui nilai $\mathrm{f}_{\text {hitung }}$ posttest sebesar 0,609 dengan signifikasi 0,438. Dari hasil perhitungan harga signifikasi data posttest lebih besar dari 0,05 
(signifikasi>0,05). Sebuah data dapat dikatakan homogen apabila harga signifikan data lebih besar dari 0,05 (signifikasi>0,05). Hasil perhitungan dari harga signifikan data posttest lebih besar dari 0,05 (signifikasi>0,05) maka dapat disimpulkan bahwa data dalam penelitian ini memiliki varians data yang homogen.

\section{Uji Hipotesisi Penelitian}

Uji ini dilakukan untuk mengetahui signifikasi perbedaan hassil belajar IPA pada kelas kontrol dan kelas eksperimen. Hasil dari uji Independent Sample Test (ujit) disajikan pada Tabel 6 berikut.

Tabel 6. Hasil Uji-t pada Kelas Kontrol dan Kelas Eksperimen

\begin{tabular}{|l|l|l|l|l|}
\hline $\begin{array}{l}\text { Hasil } \\
\text { Belajar }\end{array}$ & $\mathbf{t}_{\text {hitung }}$ & $\mathbf{t}_{\text {tabel }}$ & $\begin{array}{l}\text { Sig. (2- } \\
\text { tailed) }\end{array}$ & Ket. \\
\hline $\begin{array}{l}\text { Nilai } \\
\text { Posttest }\end{array}$ & 4.770 & 60 & 0.000 & $\begin{array}{l}\text { Berbeda } \\
\text { secara } \\
\text { Signifikan }\end{array}$ \\
\hline
\end{tabular}

Berdasarkan hasil uji-t diketahui bahwa nilai Signifikan (2-tailed) < 0,05 yaitu 0,000. Hal ini menunjukkan bahwa terdapat perbedaan yang signifikan antara hasil belajar peserta didik kelas kontrol dan hasil belajar peserta didik pada kelas eksperimen setelah adanya pembelajaran. Dengan demikian, $\mathrm{H}_{0}$ ditolak dan $\mathrm{H}_{1}$ diterima yakni bahwa terdapat pengaruh model pembelajaran Problem Based Learning (PBL) pada pembelajaran IPA materi Pencemaran Lingkungan terhadap hasil belajar peserta didik kelas VII SMP.

Berdasarkan Tabel 3. peserta didik pada kelas kontrol mendapatkan ketuntasan sebesar $58,06 \%$ yakni terdapat 18 peserta didik yang mendapatkan predikat tuntas dan 13 peserta didik mendapatkan predikat belum tuntas, sedangkan pada kelas eksperimen yang mendapatkan ketuntasan sebesar $90,32 \%$, yakni terdapat 28 peserta didik yang mendapatkan predikat tuntas dan 3 peserta didik memperoleh predikat belum tuntas. Jadi, dapat diketahui bahwa hasil belajar peserta didik kelas eksperimen lebih baik dibanding dengan hasil belajar peserta didik kelas kontrol dengan menggunakan metode ceramah. Perbedaan yang menonjol antara hasil posttest kelas kontrol dan kelas eksperimen adalah adanya perlakuan yang berbeda antara kelas tersebut. Pada kelas kontrol, guru menerapkan metode ceramah dalam menyampaikan materi Pencemaran Lingkungan, sedangkan pada kelas eksperimen guru menerapkan model Problem Based Learning (PBL) dalam menyampaikan materi Pencemaran Lingkungan selama proses pembelajaran dalam 2 kali pertemuan (5 jam pelajaran).

Penerapan model pembelajaran Problem Based Learning (PBL) dalam menyampaikan materi Pencemaran Lingkungan pada kelas eksperimen memiliki kelebihan. Kelebihan penggunaan model pembelajaran Problem Based Learning (PBL) adalah membantu peserta didik mengembangkan kemampuan investigasi dan keterampilan dalam mengatasi masalah-masalah yang ada dalam kehidupan sehari-hari, peserta didik akan terlibat aktif selama proses pembelajaran, peserta didik dapat menemukan sendiri konsep IPA melalui kegiatan praktikum yang dilakukan, dan peserta didik tidak hanya sebatas mendengarkan penjelasan dari guru, melainkan guru berperan sebagai fasilitator sehingga peserta didik mendapatkan rasa percaya diri atas kemampuannya sendiri serta menjadi pelajar yang mampu mengatur sendiri belajarnya (Arends, 2008). Pembelajaran dengan model Problem Based Learning (PBL) akan lebih bermakna karena peserta didik akan memperoleh pengetahuan berdasarkan pengalaman yang telah dilakukan selama proses pembelajaran berlangsung.

Setelah dilakukan pembelajaran dengan menggunakan model PBL, hasil belajar kognitif peserta didik sebanyak 28 dari 31 peserta didik mendapat predikat tuntas. Ketuntasan tersebut menunjukkan bahwa pembelajaran IPA materi pencemaran lingkungan dengan menggunakan model PBL berpengaruh positif terhadap hasil belajar kognitif peserta didik. Model PBL berpengaruh terhadap hasil belajar posttest peserta didik tidak lepas dari peranan guru dan peserta didik dalam mencapai tujuan pembelajaran. Hal ini sesuai dengan pernyataan Karwati \& Priansa (2014) bahwa keberhasilan dapat dicapai oleh peserta didik apabila hubungan guru dan peserta didik berjalan dengan baik, 
saling memberikan respon baik antara satu dengan yang lain dalam proses pembelajaran. Hal ini sesuai dengan hasil penelitian Purwandi (2017: 8) bahwa terdapat perbedaan hasil belajar antara peserta didik yang diberikan pembelajaran dengan menggunakan model Problem Based Learning (PBL) dan peserta didik yang diberikan pembelajaran dengan metode ceramah, sehingga model Problem Based Learning (PBL) dapat mempengaruhi hasil belajar dan aktivitas peserta didik

Berdasarkan Gambar 1. diperoleh data sebanyak 3 Indikator Pembelajaran pada kelas kontrol mendapatkan predikat tidak tuntas, sedangkan 2 Indikator Pembelajaran pada kelas eksperimen mendapatkan predikat tuntas. Pada kelas kontrol dan kelas eksperimen, yang membedakan tingkat KIP ada pada indikator pembelajaran 3.8.7. yaitu memprediksi dampak negatif dari pencemaran air. Indikator tersebut menuntut peserta didik untuk berpikir tingkat tinggi pengenai dampak negatif yang akan timbul akibat adanya pencemaran air di lingkungan sekitar. Kelas kontrol mendapat predikat tidak tuntas sebesar 69,35\% sedangkan pada kelas eksperimen mendapat predikat tuntas dengan ketuntasan sebesar 85,48\%, dari hasil tersebut dapat dilihat bahwa terdapat perbedaan yang sangat jauh antara kelas kontrol dan kelas eksperimen.

Hasil rekapitulasi data posttest pada setiap indikator pembelajaran pada kelas kontrol dan kelas eksperimen menunjukkan seberapa besar ketuntasan yang dicapai oleh peserta didik pada setiap indikator pembelajaran melalui soal posttest yang diberikan setelah pembelajaran dilangsungkan. Pada kelas kontrol terdapat 3 indikator yang belum bisa dituntaskan oleh peserta didik yaitu menjelaskan pengertian pencemaran lingkungan; menjelaskan pengertian pencemaran air; dan memprediksi dampak negatif dari pencemaran air, ketiga indikator tersebut memiliki tingkat kesulitan pada taraf ranah kognitif $\mathrm{C} 2, \mathrm{C} 3$, dan $\mathrm{C} 4$ secara berturutturut. Ketidaktuntasan indikator pembelajaran dikarenakan pada saat pembelajaran berlangsung, peserta didik tersebut memiliki daya tangkap dalam mempelajari materi pembelajaran kurang maksimal. Pada indikator pembelajaran yang tidak tuntas, peserta didik tidak mampu menjawab pertanyaan yang tertera pada soal dengan benar, sebagian besar peserta didik mengalami kesalahan dalam menjawab soal. Hal tersebut dapat ditinjau dari kualitas soal yang diberikan oleh guru kepada peserta didik, dan juga sebagian besar peserta didik yang kurang mampu memahami serta memilih pernyataan yang benar sesuai dengan yang diberikan oleh guru pada pilihan jawaban.

Sedangkan rekapitulasi dada kelas eksperimen terdapat 2 indikator pembelajaran yang belum bisa dituntaskan oleh peserta didik yaitu menjelaskan pengertian pencemaran lingkungan; menjelaskan pengertian pencemaran air, kedua indikator tersebut memiliki taraf ranah kognitif $\mathrm{C} 2$, dan $\mathrm{C} 3$ secara berturutturut. Berdasarkan pada lampiran, ketidaktuntasan indikator pembelajaran dikarenakan pemahaman beberapa peserta didik terhadap indikator pembelajaran masih kurang maksimal. Akan tetapi, terdapat berbedaan yang menonjol antara kelas kontrol dan kelas eksperimen yaitu pada indikator pembelajaran memprediksi dampak negatif dari pencemaran air. Pada kelas kontrol peserta didik secara keseluruhan belum mampu menuntaskan indikator tersebut dikarenakan pada taraf ranah kognitif memasuki ranah $\mathrm{C} 4$. Kelas kontrol dibelajarkan dengan menggunakan metode ceramah, sehingga belum sepenuhnya bisa memecahkan masalahnya sendiri karena pengajaran masih berpusat pada guru dan peserta didik berperan pasif dalam proses pembelajaran sehingga belum bisa mengasah kemampuan berpikir kritisnya.

Pada kelas eksperimen, peserta didik dituntut untuk bisa mengatasi masalah yang ada dan dihubungkan dengan kehidupan sehri-hari, sehingga ketika peserta didik dihadapkan dengan soal yang berkaitan dengan kemampuan memecahkan masalah mereka dapat mengatasi hal tersebut, terbukti dengan hasil ketuntasan indikator "memprediksi dampak negatif dari pencemaran air", peserta didik secara keseluruhan mendapat predikat tuntas. Model pembelajaran Problem Based 
Learning (PBL) menuntut peserta didik untuk dapat mengilustrasikan masalahmasalah kedalam kehidupan nyata seperti pada materi pencemran lingkungan, peserta didik mengamati dan terjun langsung dalam masalah yang ada di kehidupan nyata. Hal ini membuat peserta didik aktif selama proses pembelajaran dan guru hanya berperan sebagai fasilitator yang membantu peserta didik ketika mengalamai kesulitan (Nurdiansyah \& Eni: 2016).

Berdasarkan Tabel 4. menunjukkan bahwa hasil uji normalitas posttest pada kelas kontrol mendapatkan nilai signifikasi sebesar 0,053. Sedangkan hasil uji normalitas posttest pada kelas eksperimen mendapatkan nilai signifikasi sebesar 0,058 . Sebuah data dapat dikatakan berdistribusi normal apabila nilai signifikasi $>0,05$ dan jika nilai signifikasi $<0,05$ maka data tidak berdistribusi normal. Hasil uji normalitas posttest baik kelas kontrol maupun kelas eksperimen memiliki nilai signifikasi $>0,05$, maka dapat disimpulkan bahwa kelompok data tersebut berdistribusi normal. Sedangkan pada Tabel 5. hasil uji homogenitas variabel penelitian diketahui nilai $\mathrm{f}_{\text {hitung }}$ posttest sebesar 0,609 dengan signifikasi 0,438 . Dari hasil perhitungan harga signifikasi data posttest lebih besar dari 0,05 (signifikasi $>0,05$ ). Sebuah data dapat dikatakan homogen apabila harga signifikan data lebih besar dari 0,05 (signifikasi>0,05). Hasil perhitungan dari harga signifikan data posttest lebih besar dari 0,05 (signifikasi>0,05) maka dapat disimpulkan bahwa data dalam penelitian ini memiliki varians data yang homogen.

\section{DAFTAR PUSTAKA}

Arends, R. (2008). Learning to Teach (Belajar untuk Mengajar)Edisi Ketujuh/Buku Dua. Yogyakarta: Pustaka Belajar.

Kemendikbud. (2014a). Ilmu Pengetahuan Alam. Jakarta: Kementerian Pendidikan dan Kebudayaan.

Kemdikbud. (2014b). Konsep dan Implementasi Kurikulum 2013. (Online), (http://kemdikbud.go.id, diakses 14 September 2018).
Berdasarkan hasil uji-t diketahui bahwa nilai Signifikan (2-tailed) $<0,05$ yaitu 0,000. Hal ini menunjukkan bahwa terdapat perbedaan yang signifikan antara hasil belajar peserta didik kelas kontrol dan hasil belajar peserta didik pada kelas eksperimen setelah adanya pembelajaran. Dengan demikian, $\mathrm{H}_{0}$ ditolak dan $\mathrm{H}_{1}$ diterima yakni bahwa terdapat pengaruh model pembelajaran Problem Based Learning (PBL) pada pembelajaran IPA materi Pencemaran Lingkungan terhadap hasil belajar peserta didik kelas VII SMP Negeri 1 Jombang. Pengaruh penggunaan model PBL dibuktikan dengan hasil uji hipotesis (uji-t) yang dilakukan yaitu $t_{\text {hitung }}$ sebesar $4,770>\mathrm{t}_{\text {tabel }} 2,00$.

\section{SIMPULAN}

Berdasarkan analisis dan pembahasan hasil penelitian pembelajaran IPA dengan model Problem Based Learning (PBL) pada materi pencemaran lingkungan, diperoleh simpulan bahwa ketuntasan indikator pembelajaran kelas kontrol memiliki predikat belum tuntas dengan nilai rata-rata sebesar 76\%, sedangkan pada kelas eksperimen memiliki predikat tuntas dengan nilai rata-rata sebesar $89 \%$. Model Problem Based Learning berpengaruh terhadap hasil belajar peserta didik kelas VII SMP pada materi Pencemaran Lingkungan dikarenakan hasil uji hipotesis (uji-t) yang dilakukan yaitu $t_{\text {hitung }}$ sebesar $4,770>t_{\text {tabel }}$ 2,00 .

Kemenristek. (2003). UU No. 20 Tahun 2003.

(Online). (http://kelembagaan.ristekdikti.go.id, diakses 14 September 2018).

Karwati, E \& Priansa. (2014). Manajemen Class (Classroom Management). Bandung: Alfabeta.

Nurdyansyah \& Eni, F. F. (2016). Inovasi Model sesuai Kurikulum 2013. Sidoarjo: Nizamia Learning Center.

Permendikbud tahun 2016 nomor 21 tentang Standar Isi Pendidikan 
(Online), (http://kemdikbud.go.id, diakses 15 September 2018).

Yulianingtias, H. P., Vanny. M. A. T \& Anang, W. M. D. (2016) Pengaruh Model Problem-Based Learning (Pbl) Terhadap Hasil Belajar Siswa Pelajaran IPA Kelas VII SMP Negeri 3 Palu. (Online). e-Jurnal Mitra Sains, Volume 4 Nomor 2 April 2016. (https:// jurnal.untad.ac.id), diakses pada 23 September 2018.

Undang-Undang No. 20 Tahun 2003 tentang Ssistem Pendidikan Nasional (Online). (http://kelembagaan.ristekdikti.go.id, diakses 15 September 2018).

Wahyudi, B. S., Slamet. H. \& Sufiyah. A. H. (2014). Pengembangan Bahan Ajar Berbasis Model Problem Based
Learning Pada Pokok Bahasan

Pencemaran Lingkungan untuk Meningkatkan Hasil Belajar Siswa Kelas X SMA Negeri Grujugan Bondowoso. (Online). (http://jurnal.unej.ac.id).

Wisudawati, A. W., \& Eka S. (2015) Metodologi Pembelajaran IPA. Yogyakarta: Bumi Aksara.

Yulianingtias, H. P., Vanny. M. A. T \& Anang, W. M. D. (2016) Pengaruh Model Problem-Based Learning (Pbl) Terhadap Hasil Belajar Siswa Pelajaran IPA Kelas VII SMP Negeri 3 Palu. (Online). e-Jurnal Mitra Sains, Volume 4 Nomor 2 April 2016. (https:// jurnal.untad.ac.id), diakses pada 23 September 2018. 